\title{
Does energy-environmental Kuznets curve hold for Ethiopia? The relationship between energy intensity and economic growth
}

\author{
Shemelis Kebede Hundie ${ }^{1 *}$ (D) and Megersa Debela Daksa ${ }^{2}$
}

*Correspondence:
shimelis2012ju@gmail.com
${ }^{1}$ School of Policy Studies,
Ethiopian Civil Service
University, Addis Ababa,
Ethiopia
Full list of author information
is available at the end of the
article

*Correspondence: shimelis2012ju@gmail.com Ethiopian Civil Service University, Addis Ababa article

\begin{abstract}
Reducing energy intensity is an important element for Ethiopia to achieve its ambitious climate-resilient growth goals. Understanding the factors that determine energy intensity plays a crucial role for academics and policymakers to formulate sound energy conservation and energy efficiency policies. This article investigates drivers of energy intensity in Ethiopia over the period of 1974-2014. The ARDL bounds test approach to cointegration and FMOLS-based Hansen parameter instability test methods were applied to examine the long-run relationship among the variables. The result reveals that there is an inverted U-shape or Environmental Kuznets curve-type relationship between economic growth and energy intensity, implying that economic growth at early (industrialization) stage of development spurs energy intensity while delinking occurs at the later stages of development. Urbanization increases energy intensity, while impact of import is negative. The Toda-Yamamoto Granger causality test result shows a bidirectional causal relationship between import and energy intensity. Moreover, energy intensity Granger causes aid and industrialization.
\end{abstract}

Keywords: Energy intensity, Economic growth, FMOLS, ARDL, Ethiopia

\section{Introduction}

Energy plays critical role in bringing the sustainable development. However, when not used efficiently, its negative consequences on any economy is enormous. This could be related to threatening the sustainable development of the economy, energy security and worsening the environmental conditions (Adom and Kwakwa 2014). Challenges like climate change and energy security that world economy is facing the in the twenty first century is mainly due to energy consumption. Since anthropogenic emissions of carbon dioxide $\left(\mathrm{CO}_{2}\right)$ result predominantly from the combustion of fossil fuels, energy consumption is at the focus of the climate change debate. According to U.S Energy Information and Administration (EIA) (2016), world energy-related $\mathrm{CO}_{2}$ emissions increase from 32.3 billion metric tons in 2012 to 35.6 billion metric tons in 2020 and to 43.2 billion metric tons in 2040.

Efficient energy utilization has a great role in an economy. Promoting energy efficiency has several potential benefits which consist of promoting market 
competitiveness, saving energy cost, creating a low carbon economy and improving clean energy access. The energy intensity ratio is closely related to the energy efficiency concept (Adom and Kwakwa 2014).

The energy intensity, which is measured as the ratio of energy consumption to the gross domestic product, is one of the most common indicators in the international energy policy evaluations. It has frequently been considered a proxy of a nation's energy efficiency (Ma and Yu 2017; Metcalf 2008; O'Neill and Chen 2002; Salim et al. 2017; Zhang et al. 2016). Energy intensity is a standard way to measure the link between energy use and economic development (Kander et al. 2017). Moreover, it is a key determinant of the projections of future energy demands (Soni et al. 2017).

Levels of energy intensity remain high in Africa. This situation has raised worries about the possible effect of the current energy consumption patterns on the energy balance in the region's atmosphere, environmental sustainability, reduction in greenhouse gas emissions and food security (Adom 2015). A continuous decline in energy intensity will determine the economic activities of a country toward a more sustainable path (Ma and Yu 2017). An appropriate selection of policy intervention on energy conservation needs to know the underlying causes of energy intensity because it is both an essential step to energy conservation and a rough basis for projecting the requirements of energy consumption besides the related environmental effects. But, accurate information on the impact of factors such as economic growth on the energy intensity in Africa in general and in Ethiopia in particular has not been studied thoroughly so far.

Ethiopia has large energy resources that need to be exploited to speed up its socioeconomic development. Regardless of the presence of a variety of energy resources, the bulk of the national energy consumption is met from biomass energy sources. According to the Ethiopian Environmental Protection Agency (EEPA 2004), about 95\% of the total population in Ethiopia uses biomass fuels for their main source of energy. Even though urban households have better access to modern energy than the rural population, the difference in biomass use is not large-approximately $99 \%$ of rural households compared to $94 \%$ of urban households. The heavy dependence and inefficient utilization of biomass resources have contributed to the depletion of forest resources in Ethiopia (Beyene and Koch 2013).

Due to fast growing economy, energy consumption and production in Ethiopia have been increasing but with a widening gap, leading to an increase in imports and energy insecurity. Along with energy consumption, $\mathrm{CO}_{2}$ impacts have increased as the energy consumption is mainly from biomass energy source (Ramakrishna 2014). Due to the dependence on biomass for cooking, $\mathrm{CO}_{2}$ emissions in Ethiopia have increased from 5.1 million tons in 2005 to 6.5 million tons in 2010 (Mondal et al. 2018).

To avoid such negative effects, the government has developed a strategy to build a green economy. The Climate-Resilient Green Economy (CRGE) initiative developed by the country follows a sectoral approach and has so far identified and prioritized more than 60 initiatives, which could help the country achieve its development goals while limiting $2030 \mathrm{GHG}$ emissions to around today's $150 \mathrm{Mt} \mathrm{CO}_{2} \mathrm{e}$-around $250 \mathrm{Mt} \mathrm{CO}_{2} \mathrm{e}$ less than estimated under a conventional development path (Federal Democratic Republic of 
Ethiopia (FDRE) 2011). Therefore, in achieving this goal, efficient utilization of energy and knowing factors behind it play a crucial role.

The impact of economic growth on energy intensity has been the subject of extensive debate in the energy literature (Csereklyei and Stern 2015). Survey of the empirical literature reveals that empirical studies on the relationship between economic growth and energy intensity can be grouped into three main strands. The first strand of the literature deals with determinants of energy intensity in which economic growth plays a central role (see Filipovic et al. 2015; Jiang and Ji 2016; Jimenez and Mercado 2014; Metcalf 2008; Sadorsky 2013; Song and Zheng 2012). This line of research argues that economic growth has linear positive/negative effect on energy intensity. Evidences show that rising per capita income contributes to declines in energy intensity, primarily through improvements in energy efficiency (see Galli 1998; Jiang and Ji 2016; Mahmood and Ahmad 2018; Metcalf 2008; Sadorsky 2013; Song and Zheng 2012; Yan 2015). Contrary, it is asserted that a higher income increases the demand for energy and hence escalates energy intensity (e.g., Burke and Csereklyei 2016; Rafiq et al. 2016; Sineviciene et al. 2017).

The second theme of the literature focus on testing the validity of Environmental Kuznets Curve (EKC), known as energy-EKC/decoupling or dematerialization hypothesis, in the framework of energy intensity. The energy-EKC hypothesis states that there is inverted U-shape between energy intensity and economic growth. This hypothesis is supported by several empirical studies (e.g., Aboagye 2017; Bilgili 2017; Galli 1998; Jakob et al. 2012; Jiang and Lin 2012). However, the energy-EKC hypothesis has not been established on the solid ground and the empirical findings related to the hypothesis are sensitive to situations like type of variables included and level of economic development. For example, Kander et al. (2017) contended that the clear inverted U-shaped curve in German energy intensity without trade adjustment is reduced when trade is accounted for.

On the other hand, some authors (for example, Lescaroux 2011) criticized that it is wrong to accept a bell shape of energy intensity-economic growth relationship for granted. The shape may be dependent on initial conditions, variables included in the model and the availability of modern commercial energy resources. The energy-EKC hypothesis is sensitive to the inclusion/exclusion of energy embodied in trade (Kander et al. 2017) and energy prices (Richmond and Kaufmann 2006). Moreover, Jakob et al. (2012) claim that energy-EKC hypothesis holds only in high-income countries. There are empirical studies that do not support the energy-EKC hypothesis (Csereklyei and Stern 2015; Jakob et al. 2012; Luzzati and Orsini 2009; Moreau and Vuille 2018). In contrast to the inverted U-shape, some pieces of the literature also suggest an S-shaped relationship between economic growth and energy intensity (Medlock and Soligo 2001; Smil 2003; van Benthem 2015; van Benthem and Romani 2009).

The third strand of the literature deals with testing of convergence in energy intensity across countries. These empirical literatures examine two types of convergences: sigma-convergence and beta-convergence (Deichmann et al. 2018a). Sigma-convergence tests whether energy intensity across counties is getting smaller, while beta-convergence examines whether less efficient countries reduce their energy intensity faster than more efficient ones. Majority of the empirical studies support the convergence hypothesis (see 
Bulut and Durusu-Ciftci 2018; Burke and Csereklyei 2016; Csereklyei and Stern 2015; Ezcurra 2007; Hajko 2014; Herrerias 2012; Jakob et al. 2012; Jiang et al. 2018; Karimu et al. 2017; Kiran 2013; Liddle 2010; Mulder and de Groot 2012) but, the result is sensitive to different issues. For example, the finding might be affected by structural breaks (Karimu et al. 2017), size of data set (Liddle 2010), types of estimates (Hajko 2014), sector (Jiang et al. 2018), and geographical differences (Liddle 2010); OECD and Eurasian countries show greater convergence than SSA, while convergence is absent in Latin American, Caribbean, North East and North Africa. On the other hand, Pen and Sévi (2010)found that global convergence hypothesis did not hold for a group of 97 countries during 1971-2003 but, local convergence is weakly supported.

This short-lived survey of the literature shows several gaps with the existing literature. Firstly, most global energy models are developed focusing primarily on issues that are important in industrialized countries. Given the fast growing importance of energy trajectories of developing countries for global sustainability, there is a need to develop energy models in the way that can better capture the dynamics of energy systems in developing countries (van Ruijven et al. 2008). Secondly, almost all of the previous studies were conducted using panel data. But, the cross-sectional (or panel) regression model test of $\beta$-convergence has been criticized (Bulut and Durusu-Ciftci 2018) because it can only test the hypothesis that whether all countries in the sample are converging or not; therefore, it cannot satisfactorily address country-specific issues (Bernard and Durlauf 1995). Moreover, Evans (1996) argued that cross-country regressions are built on highly unlikely assumptions which can never be satisfied by the real data, and inferences drawn from cross-sectional analyses are misleading because of the inappropriateness of these data for analyzing dynamic behavior of the data (Quah 1993). Therefore, energy consumption dynamics can only be analyzed at the level of individual countries because of heterogeneity of developing countries as argued in Blanchard (1992). Thirdly, the three strands of the literature on the relationship between energy intensity and economic growth presents mixed and inconclusive evidences.

Moreover, to our knowledge, there is no research conducted on testing the existence of energy-EKC hypothesis in Ethiopia so far.

It is against this backdrop that this study examines the impact of economic growth on energy intensity in Ethiopia in the context of energy-EKC hypothesis for the first time, to the level of our knowledge. This article uniquely contributes to the energy literature in that it applies recently developed econometric techniques which have advantageous over the conventional ones. Moreover, robustness of the result has been checked as the EKC hypothesis is too sensitive to the econometric method used.

The rest of the paper is structured as follows. Section 2 of the article outlines methods and data. Section 3 presents findings and discussions of the study. Finally, conclusion and policy implication is presented in Sect. 4 .

\section{Materials and methods}

\subsection{Model specification}

Empirical literature reveals that energy intensity is influenced by several macroeconomic variables. Following Sadorsky (2013), this study used logarithm of income, logarithm of urbanization, logarithm of industrialization as potential determinants of intensity energy 
intensity in Ethiopia. Moreover, logarithm of import and logarithm of aid are included into equation of energy intensity based on Hübler and Keller (2010). In order to test the existence of energy-EKC hypothesis, logarithm of income squared is also included as an independent variable based on Deichmann et al. (2018b), Filipovic et al. (2015), Jiang and Lin (2012), Dong et al. (2016) and Zhang et al. (2016). Accordingly, the relationship between energy intensity $(E)$ measured as the ratio of energy use to GDP, income $(Y)$ proxied by GDP, income squared $\left(Y^{2}\right)$ measured as GDP squared, urbanization $(U)$ measured as percentage of urban population, aid $(A)$ measured as the ratio of foreign aid to GDP, industrialization (In) proxied by the ratio of industrial sector GDP to total GDP and import (Im) measured as the ratio of import to GDP, all variables in natural logarithm form, is specified as:

$$
\ln E_{t}=\alpha+\beta_{1} \ln Y_{t}+\beta_{2}\left(\ln Y_{t}\right)^{2}+\beta_{3} \ln U_{t}+\beta_{4} \ln I_{t}+\beta_{5} A_{t}+\beta_{6} \ln \operatorname{Im}_{t}+\varepsilon_{t} .
$$

\subsection{Data}

This study uses annual time series data covering the period from 1970 to 2014 . The following variables were considered for the study; energy intensity, GDP, square of GDP, urbanization, industrial sector GDP (industrialization), foreign aid and import. All variables except industrialization were obtained from the World Bank Development Indicators database. Industrialization variable was obtained from the Ethiopian Economics Association database.

\subsection{Estimation techniques}

\subsubsection{Unit root tests}

Even though several conventional unit root tests are available to test the stationarity properties of the variables, they were not used in this study because Katircioglu (2014) and Muhammad et al. (2013) argued that they provide biased and spurious results due to ignoring structural break in the series. To this end, this study employed unit root tests which consider structural break/s in the series.

Zivot and Andrews (1992) (ZA hereafter) test the stationarity properties of the variables in the presence of single structural break point in the series with three options: a one-time change in variables at level form, a one-time change in the slope of the trend component and a one-time change both in intercept and the trend function of the variables. It can be captured by the following model.

$$
\begin{aligned}
& \Delta x_{t}=\alpha+\alpha x_{t-1}+\beta t+\phi D U_{t}+\sum_{j=1}^{k} d_{j} \Delta x_{t-j}+\varepsilon_{t} \\
& \Delta x_{t}=\alpha+\alpha x_{t-1}+\phi t+\beta D T_{t}+\sum_{j=1}^{k} d_{j} \Delta x_{t-j}+\varepsilon_{t} \\
& \Delta x_{t}=\phi+\phi x_{t-1}+\phi t+\gamma D U_{t}+\gamma D T_{t}+\sum_{j=1}^{k} d_{j} \Delta x_{t-j}+\varepsilon_{t}
\end{aligned}
$$


where $D U_{t}$ indicates dummy variable showing mean shift occurred at point with time break, while $D T_{t}$ is trend shift variable. Model 4 is used for empirical estimation. Accordingly,

$$
\mathrm{DU}_{t}=\left\{\begin{array}{ll}
1 \ldots \text { if } t>\mathrm{TB} \\
0 \ldots \text { if } t<\mathrm{TB}
\end{array} \text { and } \mathrm{DU}_{t}= \begin{cases}t-\mathrm{TB} \ldots & \text { if } t>\mathrm{TB} \\
0 \ldots & \text { if } t<\mathrm{TB}\end{cases}\right.
$$

The null hypothesis of unit root break date is $\phi=0$ which indicates that the series is not stationary with a drift not having information about structural break point, while $\phi<0$ hypothesis implies that the variable is found to be trend-stationary with one unknown time break.

It is common for macroeconomic variables to exhibit the presence of multiple breaks. In this case, the unit root test method proposed by Clemente et al. (1998) (CMR hereafter) which takes two break dates was used in this study in addition to ZA method. The model has two forms: the additive outliers (the AO model) and the innovative outliers (the IO model).

We wish to test the null hypothesis:

$H_{0}: y_{t}=y_{t-1}+\delta_{1} D T B_{1 t}+\delta_{2} D T B_{2 t}+u_{t}$ as against the alternative hypothesis:

$$
H_{1}: y_{t}=\mu+d_{1} D U_{1 t}+d_{2} D U_{2 t}+\varepsilon_{t}
$$

where $D T B_{i t}$ is a pulse variable that takes the value 1 if $t=T B_{i}+1(i=1,2)$ and 0 otherwise, $D U_{i t}=1$ if $t>T B_{i}(i=1,2)$ and 0 otherwise. $T B_{1}$ and $T B_{2}$ are the time periods when the mean is being modified.

The unit root hypothesis testing if the two breaks belong to the innovational outlier takes place by first estimating the following model and testing whether $\rho=1$ :

$$
y_{t}=\mu+\rho y_{t-1}+\delta_{1} \mathrm{DU}_{1 t}+\delta_{2} \mathrm{DU}_{2 t}+d_{1} \mathrm{DT}_{b 1, t}+d_{2} \mathrm{DT}_{b 2, t}+\sum_{i=1}^{k} c_{i} \Delta y_{t-i}+\varepsilon_{t}
$$

If the shifts are supposed to be better represented as additive outliers, then we can test the unit root null hypothesis through the following two steps. The first step is to remove the deterministic part of the variable by estimating the following model:

$$
y_{t}=\mu+\delta_{1} \mathrm{DU}_{1 t}+\delta_{2} \mathrm{DU}_{2 t}+\tilde{y}_{t}
$$

Second, we carry out the test for the $\rho=1$ hypothesis in the following model:

$$
\tilde{y}_{t}=\sum_{i=0}^{k} \omega_{1 i} \mathrm{DTB}_{1 t-i}+\sum_{i=0}^{k} \omega_{2 i} \mathrm{DTB}_{2 t-i}+\rho \tilde{y}_{t-i}+\sum_{i=1}^{k} C_{i} \Delta \tilde{y}_{t-i}+\varepsilon_{t}
$$

\subsubsection{Cointegration: ARDL approach}

Due to the merits that the ARDL bounds testing approach to cointegration has over the traditional approaches to cointegration (Chindo et al. 2014; Halicioglu and Ketenci 2016; 
Hundie 2018; Shahbaz et al. 2015; Shahbaz et al. 2013); this study applied the ARDL approach to test the long-run cointegration among the variables under consideration.

The unrestricted error-correction model (UECM) version of the ARDL model for Eq. (1) is specified as follows:

$$
\begin{aligned}
\Delta \ln E_{t}= & \alpha_{1}+\sum_{i=1}^{p} \beta_{1 i} \Delta \ln E_{t-i}+\sum_{i=0}^{q_{1}} \eta_{1 i} \Delta \ln Y_{t-i}+\sum_{i=0}^{q_{2}} \gamma_{1 i} \Delta(\ln Y)_{t-i}^{2}+\sum_{i=0}^{q_{3}} \theta_{1 i} \Delta \ln U_{t-i} \\
& +\sum_{i=0}^{q_{4}} \pi_{1 i} \Delta \ln I_{t-i}+\sum_{i=0}^{q_{5}} \phi_{1 i} \Delta \ln A_{t-i}+\sum_{i=0}^{q_{6}} \omega_{1 i} \Delta \ln \operatorname{Im}_{t-i} \\
& +\delta_{1} \ln E_{t-1}+\delta_{2} \ln Y_{t-1}+\delta_{3}\left(\ln Y_{t-1}\right)^{2} \\
& +\delta_{4} \ln U_{t-1}+\delta_{5} \ln I_{t-1}+\delta_{6} \ln A_{t-1}+\delta_{7} \ln \operatorname{Im}_{t-1}+\varepsilon_{1 t}
\end{aligned}
$$

The parameters $\delta_{i}(i=1,2,3,4,5,6,7)$ are the corresponding long-run multipliers, while the parameters $\beta_{i}, \eta_{i}, \gamma_{i}, \theta_{i}, \pi_{i}, \phi_{i}, \omega_{i}$ are the short-run dynamic coefficients of the underlying ARDL model.

Investigating the presence of long-run relationship among the variables in Eq. (7) using Fisher (F) or Wald (W) statistics is the first step in the ARDL bounds testing approach to cointegration. Shahbaz et al. (2015) contended that the F-statistic is much more sensitive to lag order selection. Therefore, the proper lag length was chosen based on the Schwartz Bayesian Criterion (SBC). ${ }^{1}$ Then, a joint significance test that implies no cointegration hypothesis, $\left(H_{0}: \delta_{1}=\delta_{2}=\delta_{3}=\delta_{4}=\delta_{5}=\delta_{6}=\delta_{7}=0\right)$, counter to the alternative hypothesis, ( $\mathrm{H}_{1}$ : at least one of $\delta$ 's is different from zero) is performed for Eq. (7). $F$-statistic is compared to the critical bounds generated by Narayan (2005) because it better fits small sample observations (Narayan 2004, 2005; Narayan and Narayan 2004). If the calculated $F$-statistic greater than the upper critical bound, the null hypothesis is rejected; it indicates that cointegration exists among the variables.

If the presence of long-run relationships (cointegration) among the variables is established, the second step is to estimate the following long-run and short-run models that are represented in Eqs. (8) and (9), respectively.

$$
\begin{aligned}
\ln E_{t}= & \alpha_{2}+\sum_{i=1}^{p} \beta_{2 i} \ln E_{t-i}+\sum_{i=0}^{q_{1}} \eta_{2 i} \ln Y_{t-i}+\sum_{i=0}^{q_{2}} \gamma_{2 i}\left(\ln Y_{t-i}\right)^{2}+\sum_{i=0}^{q_{3}} \theta_{2 i} \ln U_{t-i} \\
& +\sum_{i=0}^{q^{4}} \pi_{2 i} \ln A_{t-i}+\sum_{i=0}^{q_{5}} \phi_{2 i} \ln \operatorname{In}_{1 i}+\sum_{i=0}^{q_{6}} \omega_{2 i} \ln \operatorname{Im}_{t-i}+\varepsilon_{2 t}
\end{aligned}
$$

$$
\begin{aligned}
\Delta \ln E_{t}= & \alpha_{3}+\sum_{i=1}^{p} \beta_{3 i} \Delta \ln E_{t-i}+\sum_{i=0}^{q_{1}} \eta_{3 i} \Delta \ln Y_{t-i}+\sum_{i=0}^{q_{2}} \gamma_{3 i} \Delta\left(\ln Y_{t-i}\right)^{2} \\
& +\sum_{i=0}^{q_{2}} \theta_{3 i} \Delta \ln U_{t-i}+\sum_{i=0}^{q_{3}} \pi_{3 i} \Delta \ln A_{t-i} \\
& +\sum_{i=0}^{q_{4}} \phi_{3 i} \Delta \operatorname{In}_{t-i}+\sum_{i=0}^{q_{5}} \omega_{1 i} \Delta \ln \operatorname{Im}_{t-i}+\psi E C T_{t-1}+\varepsilon_{3 t}
\end{aligned}
$$

\footnotetext{
${ }^{1}$ Pesaran and Shin (1999) argue that the Schwartz-Bayesian Criteria (SBC) is preferable to other model specification criteria because it often has more parsimonious specifications.
} 
where $\psi$ is the speed of adjustment parameter and $E C T_{t-1}$ is the lagged residuals that are obtained from the estimated cointegration model.

It is good idea to apply more than one estimator if there is concern about the robustness of the results (Narayan 2005). To this aim, the ARDL bounds test of cointegration is accompanied by an alternative single cointegration equation known as the fully modified ordinary least squares (FMOLS hereafter) estimator of Phillips and Hansen (1990) for the robustness check. The FMOLS has a benefit of fixing endogeneity and autocorrelation effects and it removes the sample bias error (Adom and Kwakwa 2014; Gokmenoglu and Taspinar 2018; Narayan 2005).

\subsubsection{Toda-Yamamoto (TY) approach to granger causality}

The existence and direction of causal relationship between variables in the model are analyzed using Toda-Yamamoto (1995) (TY hereafter) method because it has several statistical merits over conventional Granger causality testing methods (Chindo et al. 2014; Gokmenoglu and Taspinar 2018). The basic idea behind TY method is estimating a $\left(k+d_{\max }\right)$ th-order VAR where $\mathrm{k}$ is the correct lag length of the VAR model and $d_{\max }$ is the maximal order of integration. The TY representation of Eq. (1) is given as below:

$$
\begin{aligned}
& \ln E_{t}=\beta_{10}+\sum_{i=1}^{k} \theta_{1 i} \ln E_{t-i}+\sum_{i=p+1}^{k+d_{\max }} \Omega_{1 i} \ln E_{t-i}+\sum_{i=1}^{k} \delta_{1 i} \ln Y_{t-i}+\sum_{i=p+1}^{k+d_{\max }} \phi_{1 i} \ln Y_{t-i} \\
& +\sum_{i=1}^{k} \gamma_{1 i} \ln U_{t-i}+\sum_{i=p+1}^{k+d_{\max }} \psi_{1 i} \ln U_{t-i}+\sum_{i=1}^{k} \mu_{1 i} \ln A_{t-i}+\sum_{i=p+1}^{k+d_{\max }} \eta_{1 i} \ln A_{t-i} \\
& +\sum_{i=1}^{k} \vartheta_{1 i} \ln I n_{t-i}+\sum_{i=p+1}^{k+d_{\max }} \omega_{1 i} \ln \operatorname{In}_{t-i}+\sum_{i=1}^{k} \varphi_{1 i} \ln \operatorname{Im}_{t-i}+\sum_{i=p+1}^{k+d_{\max }} \mu_{1 i} \ln \operatorname{Im}_{t-i}+\varepsilon_{1 t} \\
& \ln Y_{t}=\beta_{20}+\sum_{i=1}^{k} \theta_{2 i} \ln E_{t-i}+\sum_{i=p+1}^{k+d_{\max }} \Omega_{2 i} \ln E_{t-i}+\sum_{i=1}^{k} \delta_{2 i} \ln Y_{t-i}+\sum_{i=p+1}^{k+d_{\max }} \phi_{2 i} \ln Y_{t-i} \\
& +\sum_{i=1}^{k} \gamma_{2 i} \ln U_{t-i}+\sum_{i=p+1}^{k+d_{\max }} \psi_{2 i} \ln U_{t-i}+\sum_{i=1}^{k} \mu_{2 i} \ln A_{t-i}+\sum_{i=p+1}^{k+d_{\max }} \eta_{2 i} \ln A_{t-i} \\
& +\sum_{i=1}^{k} \vartheta_{2 i} \ln \operatorname{In}_{t-i}+\sum_{i=p+1}^{k+d_{\max }} \omega_{2 i} \ln \operatorname{In}_{t-i}+\sum_{i=1}^{k} \varphi_{2 i} \ln \operatorname{Im}_{t-i}+\sum_{i=p+1}^{k+d_{\max }} \mu_{2 i} \ln \operatorname{Im}_{t-i}+\varepsilon_{2 t} \\
& \ln U_{t}=\beta_{30}+\sum_{i=1}^{k} \theta_{3 i} \ln E_{t-i}+\sum_{i=p+1}^{k+d_{\max }} \Omega_{3 i} \ln E_{t-i}+\sum_{i=1}^{k} \delta_{3 i} \ln Y_{t-i}+\sum_{i=p+1}^{k+d_{\max }} \phi_{3 i} \ln Y_{t-i} \\
& +\sum_{i=1}^{k} \gamma_{3 i} \ln U_{t-i}+\sum_{i=p+1}^{k+d_{\max }} \psi_{3 i} \ln U_{t-i}+\sum_{i=1}^{k} \mu_{3 i} \ln A_{t-i}+\sum_{i=p+1}^{k+d_{\max }} \eta_{3 i} \ln A_{t-i} \\
& +\sum_{i=1}^{k} \vartheta_{3 i} \ln \operatorname{In}_{t-i}+\sum_{i=p+1}^{k+d_{\max }} \omega_{3 i} \ln \operatorname{In}_{t-i}+\sum_{i=1}^{k} \varphi_{3 i} \ln \operatorname{Im}_{t-i}+\sum_{i=p+1}^{k+d_{\max }} \mu_{3 i} \ln \operatorname{Im}_{t-i}+\varepsilon_{3 t}
\end{aligned}
$$


The modified Wald (MWald) test is used to test the direction of causal relationship among the variables under study.

\subsubsection{Innovative accounting approach to test dynamic Granger causality}

Economic literature argued that the Granger causality approaches such as the VECM and TY Granger causality test fail to consider the relative strength of causal relation between the variables beyond the selected time period (Chindo et al. 2014; Hundie 2014). This makes the credibility of causality results obtained by the VECM and TY Granger approaches questionable. To this end, the study applied innovative accounting approach (IAA), i.e., variance decomposition method and impulse response function. Generalized forecast error decomposition and generalized impulse response developed by Pesaran and Shin (1998) which are invariant to the ordering of variables in VAR system were employed in this study.

The impulse response function is alternate of variance decomposition approach and shows the reaction in one variable due to shocks stemming in other variables. The generalized forecast error variance decomposition method shows proportional contribution in one variable due to innovative shocks stemming in other variables.

\section{Results and discussion}

We applied the ARDL bounds testing approach to investigate the long-run relationship among energy intensity, income, income squared, urbanization, industrialization, foreign aid and import in case of Ethiopia for period covering 1970-2014. The ARDL bound testing is preferred due to the fact that it is applicable irrespective of the order of integration of the series. This avoids bias due to the pretesting of the order of integration of the variables. Results in Table 1 shows that none of the variables is stationary at I (2) or beyond that order of integration for the computation of the ARDL F-statistic to be valid. In doing so, we have applied Zivot-Andrews single structural break trended and Clemente-Montane-Reyes two structural breaks unit root tests to ensure that none of the variables is integrated of order 2 or beyond. The results of both types of unit root test are reported in Table 1. Our empirical evidence reveals that all the series show unit root problem at their level but found to be integrated at I(1). This entails that the series is stationary in their first differenced form. So, it is possible for us to test the existence of a long-run relationship between energy intensity, income, income squared, urbanization, industrialization and aid in the presence of double structural break in the series over the period of 1974-2014.

The first step in applying the ARDL bounds test is to choose the appropriate lag order the variables in the model to compute the ARDL $F$-statistic because $F$-test is lag length sensitive (Shahbaz et al. 2013). So, Schwartz Bayesian Criterion (SBC) was employed to choose the lag length because it results in more parsimonious specification (Pesaran and Shin 1999). Then, $F$-test was used to investigate the long-run relationship among energy intensity, income, urbanization, industrialization, aid and import. The results of the ARDL bounds testing approach to cointegration is presented in Table 2. Calculated $F$-statistic (14.5) is greater than the upper bound critical value (4.43) at $1 \%$ level of significance. This leads us to reject the null hypothesis of no cointegration. This confirms the existence of long-run relationship among the variables. 
Table 1 Unit root tests with structural breaks Source: Own computations (2018)

\begin{tabular}{|c|c|c|c|c|c|c|c|c|}
\hline \multicolumn{7}{|c|}{ Clemente-Montanes-Reyes unit root test with double mean shifts } & \multicolumn{2}{|c|}{$\begin{array}{l}\text { Zivot-Andrews unit root } \\
\text { test allowing for a single } \\
\text { break in intercept and/ } \\
\text { or trend }\end{array}$} \\
\hline & \multicolumn{3}{|c|}{ Innovative outliers } & \multicolumn{3}{|c|}{ Additive outliers } & \multirow[t]{2}{*}{ t-statistic } & \multirow[t]{2}{*}{ Break date } \\
\hline & $t$-statistic & TB1 & TB2 & $t$-statistic & TB1 & TB2 & & \\
\hline \multicolumn{9}{|c|}{ At levels } \\
\hline InE & $-3.153(10)$ & 1993 & $2002^{* *}$ & $-3.153(0)$ & $1991^{* * *}$ & $2006^{* * *}$ & $-6.136(2)^{* * *}$ & 2003 \\
\hline $\ln Y$ & $-2.892(4)$ & $1990^{* * *}$ & $2004^{* * *}$ & $-3.697(1)$ & $1980^{* * *}$ & $2010^{* * *}$ & $-4.090(0)$ & 2001 \\
\hline $\ln U$ & $-5.661(1)^{* *}$ & $1979^{* * *}$ & $2007^{* * *}$ & $-2.606(0)$ & $1997^{* * *}$ & $2003^{* * *}$ & $-4.316(0)$ & 1992 \\
\hline $\ln \mid \mathrm{m}$ & $-1.113(12)$ & $1990^{* * *}$ & $2002^{* *}$ & $-3.143(0)$ & $1993^{* * *}$ & $2005^{* * *}$ & $-3.924(0)$ & 2005 \\
\hline $\ln A$ & $-4.210(0)$ & $1981^{* * *}$ & $1999^{* * *}$ & $-3.750(0)$ & $1982^{* * *}$ & $2003^{* * *}$ & $-2.916(1)$ & 1991 \\
\hline $\ln \ln$ & $-1.399(1)$ & $1999^{* *}$ & $2008^{* *}$ & $-2.160(0)$ & $1980^{* * *}$ & $2006^{* *}$ & $-2.476(1)$ & 1991 \\
\hline \multicolumn{9}{|c|}{$\begin{array}{l}\text { At first differ- } \\
\text { ence }\end{array}$} \\
\hline $\ln E$ & $-7.981(1)^{* *}$ & $1992^{* * *}$ & 2001 & $-7.866(1)$ & 1991 & 2003 & $-3.441(0)$ & 1979 \\
\hline $\ln Y$ & $-3.320(10)$ & $1990^{* * *}$ & $2001^{* *}$ & $-4.667(5)$ & $1989^{* * *}$ & $2002^{* * *}$ & $-6.946(0)^{* * *}$ & 1994 \\
\hline $\ln U$ & $\begin{array}{c}-33.419 \\
(0)^{* *}\end{array}$ & $1995^{* * *}$ & $2007^{* * *}$ & $-3.098(8)$ & $1995^{* * *}$ & $2010^{* * *}$ & $-8.704(0)^{* * *}$ & 1992 \\
\hline $\ln \mid \mathrm{m}$ & $-8.146(0)^{* *}$ & $1990^{* * *}$ & $1994^{* * *}$ & $-2.874(2)$ & $1989 * * *$ & $1994^{* * *}$ & $-7.547(0)^{* * *}$ & 2001 \\
\hline $\ln A$ & $-8.893(0)^{* *}$ & $1984^{* *}$ & 1996 & $-6.305(1)^{* *}$ & 1983 & 1999 & $\begin{array}{c}-13.657 \\
(0)^{* * * *}\end{array}$ & 1983 \\
\hline $\ln \ln$ & $-5.635(0)^{* *}$ & $1985^{* * *}$ & $1991^{* * *}$ & $-1.411(3)$ & 1989 & $2008^{* * *}$ & $\begin{array}{c}-13.574 \\
(0)^{* * *}\end{array}$ & 1983 \\
\hline
\end{tabular}

Statistically significant at $1 \%\left({ }^{* * *}\right), 5 \%\left({ }^{* *}\right)$ and $10 \%\left({ }^{*}\right)$ level

Table 2 ARDL bounds test result Source: Own computations (2018)

\begin{tabular}{llll}
\hline Model specification & Selected model & F-stat. & Result \\
\hline$F_{\ln E}(\operatorname{InE}|\ln A, \ln Y, \operatorname{In}| m, \ln \mid n, \operatorname{In} U, \ln Y s q r)$ & $(4,4,4,4,2,4,3)$ & $14.5^{* * *}$ & Cointegration \\
Bounds test critical values CV & $\mid(0)$ & $\mid(1)$ & \\
& $1 \%$ & 3.79 & 5.41 \\
& $5 \%$ & 2.76 & 4.12 \\
\hline
\end{tabular}

Statistically significant at $1 \%\left({ }^{* *}\right), 5 \%\left(^{* *}\right)$ and $10 \%\left({ }^{*}\right)$ level

Results of the long-run as well as short-run marginal impacts of income, income squared, urbanization, industrialization, import and aid on energy intensity are reported in Table 3 . The result shows that income has statistically significant positive effect on energy intensity, while income squared is statistically significant negative effect. This shows that energy intensity increases in early stages of development (industrialization) as the economy is transformed from labor-intensive agriculture to capital and energyintensive industries. In the later stages of development (transition to a service economy), the economy consequently moves into information-intensive services which reduces energy intensity. Therefore, energy intensity initially increases with rising incomes and then decreases-a pattern comparable to the Environmental Kuznets Curve (EKC). This result corroborates with the finding of Deichmann et al. (2018b), Filipovic et al. (2015), Jiang and Lin (2012), Zhang et al. (2016). 
Table 3 Estimated coefficients from ARDL model Source: Own computations (2018)

\begin{tabular}{|c|c|c|c|c|c|}
\hline \multicolumn{3}{|c|}{ Short-run elasticities (dependent variable: $\Delta \ln E$ ) } & \multicolumn{3}{|c|}{ Long-run elasticities (dependent variable: $\ln E$ ) } \\
\hline Variable & Coefficient & t-statistic & Variable & Coefficient & t-statistic \\
\hline$\Delta \ln E(-1)$ & -0.687392 & $-6.9698^{* * *}$ & $\ln Y$ & 8.753100 & $7.6697^{* * *}$ \\
\hline$\Delta \ln E(-2)$ & -0.621425 & $-4.7585^{* * *}$ & InYsqr & -0.941891 & $-7.7815^{* * *}$ \\
\hline$\Delta \ln E(-3)$ & -0.311150 & $-2.9659^{* * *}$ & $\ln A$ & 0.051498 & 0.6237 \\
\hline$\Delta \ln Y$ & -6.049957 & $-5.0579^{* * *}$ & $\ln \mid \mathrm{m}$ & -0.677031 & $-5.6817^{* * *}$ \\
\hline$\Delta \ln Y(-1)$ & -8.953035 & $-6.1948^{* * *}$ & $\ln \ln$ & 0.077374 & 0.5736 \\
\hline$\Delta \ln Y(-2)$ & -13.76479 & $-6.2506^{* * *}$ & $\ln U$ & 2.611322 & $3.0657^{* *}$ \\
\hline$\Delta \ln Y(-3)$ & 0.811976 & $5.6289^{* * *}$ & Constant & -25.910071 & $-6.472861^{* * *}$ \\
\hline$\Delta \ln Y_{\text {sqr }}$ & 0.561756 & $5.0660^{* * *}$ & & & \\
\hline$\Delta \ln Y_{\text {sqr }}(-1)$ & 0.974968 & $6.6726^{* * *}$ & & & \\
\hline$\Delta \ln Y_{\text {sqr }}(-2)$ & 1.363610 & $6.3428^{* * *}$ & & & \\
\hline$\Delta \ln A$ & 0.153827 & $4.4661^{* * *}$ & & & \\
\hline$\Delta \ln A(-1)$ & 0.107966 & $2.8687^{* * *}$ & & & \\
\hline$\Delta \ln A(-2)$ & -0.100412 & $-2.8980^{* * *}$ & & & \\
\hline$\Delta \ln A(-3)$ & -0.046412 & $-1.4740^{* * *}$ & & & \\
\hline$\Delta \ln \operatorname{lm}$ & -0.181375 & $-4.2123^{* * *}$ & & & \\
\hline$\Delta \ln \ln (-1)$ & 0.344688 & $5.2845^{* * *}$ & & & \\
\hline$\Delta \ln \ln (-2)$ & 0.348216 & $4.0951^{* * *}$ & & & \\
\hline$\Delta \ln \ln (-3)$ & -0.159004 & $-2.7799^{* * *}$ & & & \\
\hline$\Delta \ln \ln$ & 0.573078 & $4.9035^{* * *}$ & & & \\
\hline$\Delta \ln \ln (-1)$ & 0.081335 & $0.6898^{* * *}$ & & & \\
\hline$\Delta \ln U$ & 16.47758 & $5.6123^{* * *}$ & & & \\
\hline$\Delta \ln U(-1)$ & 34.51120 & $8.3802^{* * *}$ & & & \\
\hline$\Delta \ln U(-2)$ & 27.37220 & $7.2972^{* * *}$ & & & \\
\hline$\Delta \ln U(-3)$ & 13.77833 & $4.4696^{* * *}$ & & & \\
\hline Constant & -0.000516 & -0.0128 & & & \\
\hline$E C T(-1)$ & -1.119523 & $-13.0020^{* * *}$ & & & \\
\hline
\end{tabular}

Statistically significant at $1 \%\left({ }^{* *}\right), 5 \%\left({ }^{* *}\right)$ and $10 \%(*)$ level

The estimated result shows that urbanization has positive statistically significant impact on energy intensity. More specifically, a $1 \%$ increase in urbanization leads an increment in energy intensity by $2.6 \%$, keeping other things constant. Urbanization may affect energy intensity through various ways. Economic activities are concentrated in cities and metropolitan areas due to urbanization process, and this results in economies of scale in production. This creates opportunity for improving energy efficiency. Urbanization induces the expansion of energy-intensive industries and stimulates the realization of agricultural modernization, which further leads to an increasing energy demand. Urbanization encourages substitution of decentralized traditional wood fuel by centralized modern energy sources. Moreover, urbanization increases the demand for energy because it affects mobility and transport by increasing the amount of motorized traffic into and out of urban areas. Third, increased urbanization increases the demand for infrastructure. Growing cities, for example, increase the demand for energy-intensive products and materials as infrastructure is built. Fourth, urbanization can impact energy demand through its impact on private consumption patterns. Urbanization is accompanied by economic development, and as urban dwellers become wealthier, their consumption patterns change to include more energy-intensive products. Obvious 
examples include refrigerators, air conditioning and automobiles. The urban centers get easily connected to the national grid and this increases energy consumption. Also, urbanization ignites industrialization. This implies that as the degree of urbanization intensifies, the rate of energy usage increases through the industrialization process. This results in increased use of energy-using appliances like refrigerator. Our finding is in line with Adom and Kwakwa (2014), Rafiq et al. (2016), Sadorsky (2013), Yan (2015)and Jones (1991).

The finding further indicates that import has negative effect on energy intensity in Ethiopia during the specified period. An increase in import by $1 \%$ leads to $0.68 \%$ decrease in energy intensity, other things remain constant. This is due to the fact that imports of goods and services lead to productivity gains via stronger competition for domestic firms because of the presence of foreign-owned firms and rivaling imports. Imports directly improve productivity, especially if the imported goods have better characteristics than the domestically produced goods. Imports indirectly create productivity spillovers (technology transfer effect) via imitation of the imported products and via improved application of methods adopted together with the imported goods (Aboagye 2016; Adom and Kwakwa 2014; Hübler and Keller 2010). Moreover, import which plays important role in trade openness intensifies economic integration of the economy into the world economies which in turn facilitates the transfer of energy saving technologies. Therefore, import reduces energy intensity through the learning and demonstration (Adom and Kwakwa 2014). Our result is in line with the findings of Belloumi and Alshehry (2016), Adom and Kwakwa (2014) and Adom (2015).

The coefficient of estimated lagged ECT (Table 3) is negative and statistically significant at $1 \%$ level of significance which shows that deviation from the long-term energy intensity path due to certain shock is adjusted by $111.95 \%$ over the next year. A coefficient of the lagged error-correction term in the short-run model is about -1.12, which indicates that instead of monotonically converging to the equilibrium path directly, the error-correction process fluctuates around the long-run value in a dampening manner. However, once this process is complete, convergence to the equilibrium path is rapid (Loayza and Ranciere 2005; Narayan and Smyth 2005). All variables under consideration affect energy intensity in Ethiopia in the short-run for the period under study.

\subsection{Stability of the model}

Misspecification of model in time series data may generate biased results. This situation may diminish the explaining power of the empirical findings (Farhani and Ozturk 2015). Therefore, this study applied the cumulative sum (CUSUM) and cumulative sum squares (CUSUMSQ) of the recursive residuals in order to test for structural stability of the estimated coefficients. Figures 1 and 2 reveal that plots of CUSUM and CUSUMSQ statistics are strictly within the $5 \%$ critical bounds indicating that all the estimated coefficients of the error-correction model are stable. Therefore, the selected energy intensity model can be used to understand the decision-making policy regarding energy intensity.

\subsection{Robustness analysis}

The robustness of long-run coefficients estimated through ARDL approach was evaluated by applying an alternative single cointegrating regression, like FMOLS 


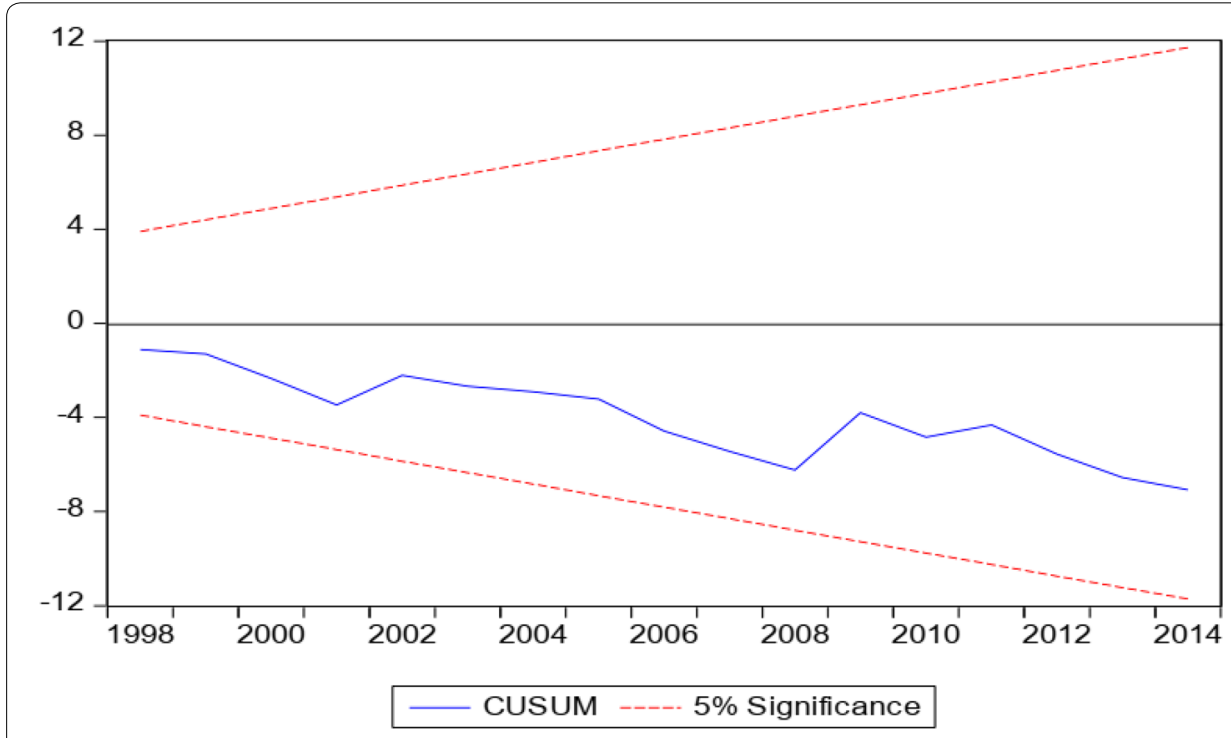

Fig. 1 Plot of CUSUM

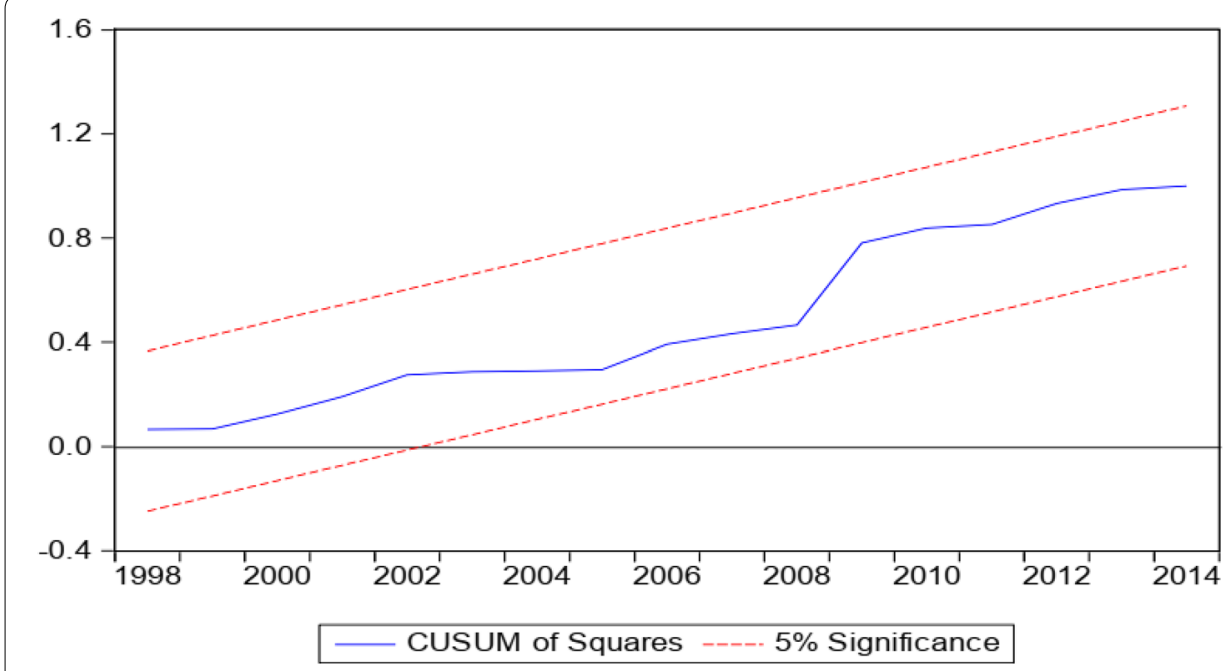

Fig. 2 Plot of CUSUMSQ

procedure. Phillips and Hansen (1990) argued that the FMOLS procedure employs a semi-parametric correction to eliminate the problems endogeneity. Moreover, it yields estimator which is asymptotically unbiased and has fully efficient mixture normal asymptotic allowing for standard Wald tests using asymptotic Chi-square statistical inference.

Table 4 shows that result from FMOLS is consistent with the ARDL according to sign and statistical significance except aid variable which turns to be statistically significant under FMOLS procedure. The result reveals that energy intensity in Ethiopia is very responsive to income and urbanization. More specifically, a $1 \%$ increase in income leads to about $2.07 \%$ rise in energy intensity, while a $1 \%$ increase in income 
Table 4 Long-run coefficients of FMOLS estimator and cointegration test Source: Own computations (2018)

\begin{tabular}{|c|c|c|c|c|}
\hline \multicolumn{3}{|c|}{ Long-run coefficients of FMOLS estimator } & \multicolumn{2}{|c|}{ Cointegration test-Hansen parameter instability } \\
\hline Variable & Coefficient & $t$-statistic & & \\
\hline $\ln Y$ & 2.0696 & $4.2055^{* * *}$ & Lc Statistic & 0.7968 \\
\hline InYsqr & -0.2140 & $-4.5117^{* * *}$ & Stochastic trends $(\mathrm{m})$ & 6 \\
\hline $\ln A$ & 0.1430 & $4.2789^{* * *}$ & Deterministic trends $(\mathrm{k})$ & 1 \\
\hline $\ln \mid \mathrm{m}$ & -0.1340 & $-4.4898^{* * *}$ & Excluded trends (p2) & 0 \\
\hline $\ln \ln$ & -0.0283 & -0.5113 & Prob. & 0.1351 \\
\hline $\ln U$ & 4.6541 & $6.8229^{* * *}$ & & \\
\hline constant & -16.883 & $-5.9252^{* * *}$ & $\mathrm{H}_{0}$ : series are cointegrated & \\
\hline @TREND & -0.1124 & $-7.6433^{* * *}$ & & \\
\hline R-squared & 0.9923 & & & $\begin{array}{l}\text { Long-run } \\
\text { variance } \\
0.0022\end{array}$ \\
\hline
\end{tabular}

Statistically significant at $1 \%\left({ }^{* * *}\right), 5 \%(* *)$ and $10 \%(*)$ level

Table 5 VAR lag order selection criteria Source: Own computations (2018)

\begin{tabular}{lllllll}
\hline Lag & LogL & LR & FPE & AIC & SC & HQ \\
\hline 0 & 25.04160 & NA & $1.63 e-08$ & -0.906743 & -0.658504 & -0.815754 \\
1 & 416.9371 & 653.1592 & $7.23 e-16$ & -17.85415 & $-16.11648^{\mathrm{a}}$ & $-17.21722^{\mathrm{a}}$ \\
2 & 462.8636 & 63.42227 & $5.02 \mathrm{e}-16$ & -18.32684 & -15.09974 & -17.14398 \\
3 & 510.0952 & $51.72990^{\mathrm{a}}$ & $3.96 \mathrm{e}-16^{\mathrm{a}}$ & $-18.86168^{\mathrm{a}}$ & -14.14515 & -17.13288 \\
\hline
\end{tabular}

$L R$ sequential modified LR test statistic (each test at $5 \%$ level), FPE final prediction error, AIC Akaike information criterion, SC Schwarz information criterion, HQ Hannan-Quinn information criterion

${ }^{\text {a }}$ Lag order selected by the criterion

square results in $21 \%$ decrease in energy intensity, ceteris paribus. Therefore, energy Kuznets curve is confirmed. When urbanization increases by $1 \%$, energy intensity increases by $4.65 \%$, keeping other things constant. Therefore, we can conclude that long-run coefficients of the energy intensity model are robust and stable.

\subsection{Granger causality test}

The first step in conducting Granger causality is appropriate VAR lag order selection. Akaike's information criterion (AIC) is used for lag length selection because Liew (2014) and Lütkepohl (2006) argued that AIC has superior power properties for small sample data as compared to other lag length criteria. Moreover, AIC provides efficient and consistent results (Shahbaz et al. 2015). Accordingly, the optimal lag length 3 (Table 5) is selected and the unit root test reveals that the maximum order of integration is one. The appropriate Granger causality test method when variables under consideration are a mixture of I(0) and I(1) is TY (Chindo et al. 2014). The TY Granger causality test procedure, in this case, estimates augmented VAR (4) and test whether coefficients of the first three lags of each independent variable jointly affect the dependent variables in the VAR (4) system.

The system of equations (Eqs. 10-12) is estimated using seemingly unrelated regression (SURE) because SURE produces coefficients which are at least asymptotically more 
Table 6 TY Granger causality test result Source: Own computations (2018)

\begin{tabular}{|c|c|c|c|c|c|c|}
\hline \multirow{3}{*}{$\begin{array}{l}\text { Dependent } \\
\text { variables }\end{array}$} & \multicolumn{6}{|c|}{ Sources of causation } \\
\hline & $\ln E$ & $\ln A$ & $\ln Y$ & InIm & $\ln \ln$ & $\ln U$ \\
\hline & $x^{2}(3)$ & $x^{2}(3)$ & $x^{2}(3)$ & $x^{2}(3)$ & $x^{2}(3)$ & $x^{2}(3)$ \\
\hline $\ln E$ & - & 2.180 & 5.396 & $35.611^{* * *}$ & 2.414 & 0.402 \\
\hline $\ln A$ & $25.465^{* * *}$ & - & $13.648^{* * *}$ & $24.414^{* * *}$ & $18.848^{* * *}$ & $10.289 * *$ \\
\hline $\ln Y$ & 3.903 & 2.983 & - & 1.015 & $11.214^{* *}$ & $6.929^{*}$ \\
\hline $\ln \mid \mathrm{m}$ & $9.071^{* *}$ & $7.322^{*}$ & 5.005 & - & 3.430 & $11.571^{* * *}$ \\
\hline $\ln \ln$ & $10.702^{* *}$ & $6.360^{*}$ & $8.888^{* *}$ & $17.394^{* * *}$ & - & $7.095^{*}$ \\
\hline $\ln U$ & 0.781 & 5.117 & 3.634 & 2.774 & 6.017 & - \\
\hline
\end{tabular}

Statistically significant at $1 \%\left({ }^{* * *}\right), 5 \%\left(^{* *}\right)$ and $10 \%\left({ }^{*}\right)$ level

efficient than those obtained by equation-by-equation application of least squares (Zellner 1962) and it makes computation of modified Wald test statistic too simple (Rambaldi and Doran 1996).

Granger causality test result is given in Table 6. The test result shows that there is a bidirectional causal relationship between energy intensity and import. This means that energy intensity Granger causes import and there is feedback from import as well. The implication of presence of two-way causal relationship between energy intensity and import suggests that any fluctuations in import may change level of energy intensity and any effort that reduces energy intensity may affect import.

The Granger causality between aid and import, between aid and industrialization, between income and industrialization is two way. Moreover, Granger causality runs from urbanization to import, income and industrialization. Urbanization and aid affect import and import in turn affects energy intensity.

\subsection{Impulse response functions and variance decompositions}

The results of generalized variance decomposition approach are described in Table 7 . The empirical evidence indicates that a $70 \%$ portion of energy intensity is contributed by its own innovative shocks and one standard deviation shock in import explains energy intensity by $48.6 \%$. Industrialization contributes to energy intensity by $3.8 \%$ due to one standard shock stemming in industrialization. The share of urbanization and economic growth in energy intensity is very minimal, i.e., 0.15 and $0.82 \%$, respectively.

The impulse response function shows the reaction in one variable due to shocks stemming in other variables. Table 8 indicated the positive response in energy intensity due to standard shocks stemming from industrialization, foreign aid and energy intensity itself. This means that industrialization and foreign aid contribute in increasing energy intensity in Ethiopia.

\section{Conclusions and policy implications}

The study examined the impact of economic growth, economic growth squared, import, aid, industrialization and urbanization on energy intensity in Ethiopia using time series data from 1974 to 2014. Clemente, Montanes and Reyes (1998) and Zivot and Andrews (1992) unit root tests which take structural breaks into account in the series were applied in order to produce a result that is not biased toward 
Table 7 Generalized forecast error variance decomposition for variable

\begin{tabular}{|c|c|c|c|c|c|c|}
\hline Horizon & InEInUInInInImInYInA & & & & & \\
\hline \multicolumn{7}{|l|}{$\ln E$} \\
\hline 0 & 1.00000 & $.1505 E-4$ & .11549 & .061921 & $.1357 \mathrm{E}-3$ & .060102 \\
\hline 1 & .93777 & $.3950 E-3$ & .086994 & .18394 & .0015471 & .036636 \\
\hline 2 & .84703 & $.8686 \mathrm{E}-3$ & .066116 & .30334 & .0035250 & .031101 \\
\hline 3 & .76715 & .0011983 & .052177 & .39227 & .0054385 & .036221 \\
\hline 4 & .70884 & .0013870 & .043206 & .45045 & .0070130 & .044326 \\
\hline 5 & .66985 & .0014858 & .037688 & .48576 & .0081854 & .051654 \\
\hline \multicolumn{7}{|l|}{$\ln U$} \\
\hline 0 & $.1505 E-4$ & 1.00000 & .031429 & .021895 & .13530 & .016029 \\
\hline 1 & $.4886 \mathrm{E}-3$ & .91157 & .028562 & .056420 & .072357 & .019650 \\
\hline 2 & .0017218 & .75864 & .021770 & .092045 & .067164 & .051479 \\
\hline 3 & .011435 & .59187 & .015664 & .12868 & .095986 & .089948 \\
\hline 4 & .030340 & .44428 & .011415 & .16989 & .12967 & .12452 \\
\hline 5 & .054050 & .32747 & .0091268 & .21866 & .15116 & .15273 \\
\hline \multicolumn{7}{|l|}{$\ln \ln$} \\
\hline 0 & .11549 & .031429 & 1.0000 & .063474 & .11411 & .034086 \\
\hline 1 & .16503 & .032528 & .92184 & .17197 & .11154 & .068562 \\
\hline 2 & .17341 & .032178 & .84559 & .25619 & .11180 & .098108 \\
\hline 3 & .16509 & .031829 & .78684 & .32085 & .11499 & .12226 \\
\hline 4 & .15101 & .031725 & .74136 & .37210 & .12001 & .14165 \\
\hline 5 & .13574 & .031862 & .70477 & .41383 & .12602 & .15701 \\
\hline \multicolumn{7}{|l|}{ LNIM } \\
\hline 0 & .061921 & .021895 & .063474 & 1.0000 & .038888 & .074147 \\
\hline 1 & .097395 & .017976 & .046992 & .97942 & .038635 & .10397 \\
\hline 2 & .13583 & .015357 & .034968 & .94703 & .038110 & .12130 \\
\hline 3 & .17323 & .013567 & .026781 & .91232 & .037375 & .12979 \\
\hline 4 & .20757 & .012309 & .021477 & .87948 & .036457 & .13287 \\
\hline 5 & .23822 & .011394 & .018251 & .84990 & .035369 & .13290 \\
\hline \multicolumn{7}{|l|}{$\ln / \mathrm{m}$} \\
\hline 0 & .061921 & .021895 & .063474 & 1.0000 & .038888 & .074147 \\
\hline 1 & .097395 & .017976 & .046992 & .97942 & .038635 & .10397 \\
\hline 2 & .13583 & .015357 & .034968 & 94703 & .038110 & .12130 \\
\hline 3 & .17323 & .013567 & .026781 & .91232 & .037375 & .12979 \\
\hline 4 & .20757 & .012309 & .021477 & .87948 & .036457 & .13287 \\
\hline 5 & .23822 & .011394 & .018251 & .84990 & .035369 & .13290 \\
\hline \multicolumn{7}{|l|}{$\ln A$} \\
\hline 0 & .060102 & .016029 & .034086 & .074147 & .012965 & 1.0000 \\
\hline 1 & .047539 & .019475 & .028341 & .057430 & .020697 & .94775 \\
\hline 2 & .044067 & .020329 & .028185 & .070247 & .026888 & .89148 \\
\hline 3 & .047355 & .019835 & .035472 & .083333 & .030582 & .84919 \\
\hline 4 & .059282 & .018913 & .054985 & .086009 & .031658 & .81326 \\
\hline 5 & .078359 & .018033 & .088847 & .081676 & .030650 & .77484 \\
\hline \multicolumn{7}{|l|}{$\ln Y$} \\
\hline 0 & $.1357 \mathrm{E}-3$ & .13530 & .11411 & .038888 & 1.0000 & .012965 \\
\hline 1 & .018447 & .13868 & .11604 & .027413 & .97596 & .013755 \\
\hline 2 & .047235 & .13720 & .10673 & .020693 & .93346 & .017322 \\
\hline 3 & .077863 & .13142 & .092193 & .031622 & .87207 & .024933 \\
\hline 4 & .10593 & .12140 & .077415 & .069138 & .79015 & .037528 \\
\hline 5 & .12866 & 10799 & .065922 & .13389 & .69216 & .054748 \\
\hline
\end{tabular}


Table 8 Generalized impulse responses to one SE shock in the equation for unrestricted vector autoregressive model

\begin{tabular}{|c|c|c|c|c|c|c|}
\hline Horizon & InEInUInInInImInYInA & & & & & \\
\hline \multicolumn{7}{|l|}{ InE } \\
\hline 0 & .081696 & $.7764 \mathrm{E}-5$ & .020526 & -.038702 & .0011504 & .048370 \\
\hline 1 & .061697 & $.6025 \mathrm{E}-4$ & .035431 & -.057778 & -.017995 & .012021 \\
\hline 2 & .052898 & $-.1286 \mathrm{E}-3$ & .041620 & -.073647 & -.028584 & .0095446 \\
\hline 3 & .049975 & $-.4236 \mathrm{E}-3$ & .042637 & -.085272 & -.034573 & .019167 \\
\hline 4 & .049786 & $-.7588 \mathrm{E}-3$ & .040831 & -.093094 & -.038318 & .030435 \\
\hline 5 & .050615 & -.0011063 & .037649 & -.098013 & -.041106 & .039148 \\
\hline \multicolumn{7}{|l|}{$\ln U$} \\
\hline 0 & $.3170 \mathrm{E}-3$ & .0020012 & .010707 & .023014 & -.036331 & -.024980 \\
\hline 1 & -.0020771 & .0016973 & .014691 & .019051 & -.033533 & -.019843 \\
\hline 2 & -.0030337 & .0014236 & .017380 & .016353 & -.029550 & -.013052 \\
\hline 3 & -.0033203 & .0011931 & .019369 & .014594 & -.025050 & -.0066691 \\
\hline 4 & -.0033282 & .0010092 & .020992 & .013437 & -.020411 & -.0013322 \\
\hline 5 & -.0032337 & $.8707 E-3$ & .022418 & .012606 & -.015838 & .0029615 \\
\hline \multicolumn{7}{|l|}{$\ln \ln$} \\
\hline 0 & .027764 & $.3548 \mathrm{E}-3$ & .060397 & .039184 & -.033365 & .036427 \\
\hline 1 & .014193 & $.2998 \mathrm{E}-3$ & .075616 & .028249 & -.030532 & .012412 \\
\hline 2 & .0080155 & $.2000 E-3$ & .085187 & .017548 & -.023138 & .012892 \\
\hline 3 & .0060422 & $.1334 \mathrm{E}-3$ & .091043 & .0082996 & -.013670 & .023602 \\
\hline 4 & .0063000 & $.1348 \mathrm{E}-3$ & .094521 & $.6440 E-3$ & -.0036953 & .037206 \\
\hline 5 & .0076485 & $.2141 E-3$ & .096476 & -.0056925 & .0058609 & .050359 \\
\hline \multicolumn{7}{|l|}{$\ln / \mathrm{m}$} \\
\hline 0 & -.020329 & $.2961 \mathrm{E}-3$ & .015216 & .15553 & -.019478 & .053726 \\
\hline 1 & -.040528 & $.5818 \mathrm{E}-3$ & .038931 & .15635 & -.010190 & -.010708 \\
\hline 2 & -.051959 & $.8094 E-3$ & .057349 & .15133 & .0041433 & -.033229 \\
\hline 3 & -.057546 & .0010797 & .071568 & .14419 & .021188 & -.032758 \\
\hline 4 & -.059445 & .0014473 & .082640 & .13665 & .039175 & -.020854 \\
\hline 5 & -.059119 & .0019355 & .091387 & .12938 & .056875 & -.0041155 \\
\hline \multicolumn{7}{|l|}{$\ln Y$} \\
\hline 0 & $.9515 E-3$ & $-.7361 \mathrm{E}-3$ & -.020402 & -.030670 & .098771 & .022465 \\
\hline 1 & .0040479 & $-.6854 \mathrm{E}-4$ & -.026776 & -.031269 & .086298 & .024018 \\
\hline 2 & .0061621 & $.4924 \mathrm{E}-3$ & -.032627 & -.030987 & .073272 & .022131 \\
\hline 3 & .0075221 & $.9419 E-3$ & -.037987 & -.030061 & .060068 & .018140 \\
\hline 4 & .0082926 & .0012797 & -.042876 & -.028617 & .046991 & .012872 \\
\hline 5 & .0085888 & .0015090 & -.047298 & -.026734 & .034287 & .0068331 \\
\hline \multicolumn{7}{|l|}{$\ln A$} \\
\hline 0 & .020028 & $-.2534 \mathrm{E}-3$ & .011151 & .042350 & .011246 & .19730 \\
\hline 1 & .0028855 & $.2902 E-3$ & .023921 & .058043 & .010769 & .10294 \\
\hline 2 & -.0088382 & $.6755 E-3$ & .035100 & .063247 & .013282 & .050723 \\
\hline 3 & -.016041 & $.9828 \mathrm{E}-3$ & .044071 & .063024 & .018155 & .025887 \\
\hline 4 & -.019916 & .0012694 & .050949 & .060290 & .024491 & .017535 \\
\hline 5 & -.021534 & .0015706 & .056097 & .056607 & .031466 & .018332 \\
\hline
\end{tabular}

non-rejection. We applied the ARDL bounds test approach to cointegration and FMOLS methods in order to test the existence of cointegration among the variables under consideration. TY approach to Granger causality was also applied to examine the direction of causal relationship among the variables. To explore the dynamic 
relationship and timing of energy intensity and its determinants, generalized impulse response and generalized forecast error decomposition were employed.

Analysis based on ARDL and FMOLS approach to cointegration shows the existence of long-run equilibrium relationship among the variables which implies that the variables exhibit common deterministic trend. Economic growth has positive effect on energy intensity. This means that economic growth which a result of increased economic activities leads to higher energy intensity because it requires more energy consumption. On the other hand, economic growth squared has negative and statistically significant effect on energy intensity implying that economic growth at higher stage of development helps reduce energy intensity. The implication is that economic growth has a threshold effect on energy intensity change.

The result also reveals that urbanization has positive impact on energy intensity. This happens due to the fact that urbanization encourages economic activities which are energy intensive. Moreover, urbanization increases energy intensity by increasing amount of motorized traffic into and out of cities, by increasing demand for infrastructure, by changing private consumption patterns and by spurring industrialization.

The result further shows that import has negative and statistically significant impact on energy intensity. Import reduces energy intensity by increasing productivity gains through firms' competition. It increases productivity, it intensifies economic integration, it creates productivity spillovers (technology transfer effect) and it intensifies economic integration of the economy into the world economies which in turn facilitates the transfer of energy saving technologies.

The finding of the study has strong theoretical and policy implications. Theoretically, the fact that economic growth affects energy intensity positively while economic growth squared has negative effect on energy intensity replicates the argument of EenergyEnvironmental Kuznets Curve (Eenergy-EKC) which corroborates with works of Deichmann et al. (2018b), Zhang et al. (2016) and Filipovic et al. 2015). The positive impact of urbanization on energy intensity was corroborated by the findings of Sadorsky (2013), Belloumi and Alshehry (2016) and Sadorsky (2013). The finding that shows import has negative energy intensity reflects the fact that international openness that are reflected in FDI, and trade openness contributed to the reduction in energy intensity (Adom 2015; Adom and Kwakwa 2014; Jiang and Ji 2016).

As policy implication, Ethiopian energy policy should focus on energy conserving strategies. More specifically, economic growth of Ethiopia which has been taking place at an alarming rate requires higher energy consumption. Currently, Ethiopia's energy consumption is predominantly dominated by biomass (traditional) energy sources which are not efficient as compared to the modern one. Therefore, policymakers should device policies through which the country's energy intensity can be reduced. More specifically, the country's energy source should be shifted from traditional energy sources to the modern ones. Energy conservation strategies should be developed; energy efficiency should be increased; and utilization of cleaner energy should be increased. In addition, the government of Ethiopia should implement sound environmental policies which encourage the import of cleaner and energy saving (efficient) technologies for reducing energy intensity. As far as urbanization is concerned, the government should pay due attention to public infrastructure at phase of design, construction and operation to be more energy 
saving and efficient. Moreover, transportation technologies should be energy efficient and the government should pay due attention to improve public awareness of energy saving so as to change the urban residents' consumption pattern and lifestyle.

Future research should focus on the impact of trade structure, foreign direct investment, energy price, structural change and the economic integration on energy intensity. Moreover, cointegration tests that consider several structural breaks should be employed to advance the knowledge relating to factors affecting energy intensity in the case of Ethiopia.

\section{Acknowledgements}

Not applicable.

\section{Authors' contributions}

SKH designed the methods of data analysis, analyzed the data and wrote the first draft of the manuscript. MDD provided guide and corrections to the entire research study. Both authors read and approved the final manuscript.

\section{Funding}

Not applicable.

Availability of data and materials

The dataset supporting the conclusions of this article would be provided on reasonable request.

\section{Competing interests}

The authors declare that they have no competing interests.

\section{Author details}

${ }^{1}$ School of Policy Studies, Ethiopian Civil Service University, Addis Ababa, Ethiopia. ${ }^{2}$ Western Michigan University, Kalamazoo, USA.

Received: 25 September 2018 Accepted: 11 June 2019

Published online: 22 June 2019

\section{References}

Aboagye S (2016) The implication of economic growth, industrialization and urbanization on energy intensity in Sub-Saharan Africa. J Appl Econ Bus Res 6(4):297-311

Aboagye S (2017) The policy implications of the relationship between energy consumption, energy intensity and economic growth in Ghana. OPEC Energy Rev. https://doi.org/10.1111/opec.12114

Adom PK (2015) Determinants of energy intensity in South Africa: testing for structural effects in parameters. Energy 89(September):334-346. https://doi.org/10.1016/j.energy.2015.05.125

Adom P, Kwakwa PA (2014) Effects of changing trade structure and technical characteristics of the manufacturing sector on energy intensity in Ghana. Renew Sustain Energy Rev 35:475-483. https://doi.org/10.1016/j.rser.2014.04.014

Belloumi M, Alshehry AS (2016) The impact of urbanization on energy intensity in Saudi Arabia. Sustainability. https://doi. org/10.3390/su8040375

Bernard AB, Durlauf SN (1995) Convergence in international output. J Appl Econom 10(2):97-108. https://doi.org/10.1002/ jae.3950100202

Beyene AD, Koch SF (2013) Clean fuel-saving technology adoption in urban Ethiopia. Energy Economics 36:605-613. https:// doi.org/10.1016/j.eneco.2012.11.003

Bilgili F (2017) The impact of urbanization on energy intensity: panel data evidence considering cross-sectional dependence and heterogeneity. Energy. https://doi.org/10.1016/j.energy.2017.05.121

Blanchard O (1992) Energy consumption and modes of industrialization four developing countries. Energy Policy 20:1174-1185

Bulut U, Durusu-Ciftci D (2018) Revisiting energy intensity convergence: new evidence from OECD countries. Environ Sci Pollut Res. https://doi.org/10.1007/s11356-018-1551-z

Burke PJ, Csereklyei Z (2016) Understanding the energy-GDP elasticity: a sectoral approach. Energy Econ 58:199-210. https:// doi.org/10.1016/j.eneco.2016.07.004

Chindo S, Abdulrahim A, Ahmad AA (2014) Energy consumption, $\mathrm{CO}_{2}$ emissions and GDP in Nigeria. GeoJournal 80:315-322. https://doi.org/10.1007/s10708-014-9558-6

Clemente J, Montanes A, Reyes M (1998) Testing for a unit root in variables with a double change in the mean. Economics Letters 59(59):175-182

Csereklyei Z, Stern DI (2015) Global energy use: decoupling or convergence? Energy Econ 51:633-641. https://doi. org/10.1016/j.eneco.2015.08.029

Deichmann U, Reuter A, Vollmer S, Zhang F (2018a) Relationship between energy intensity and economic growth (no. 8322). South Asia Region

Deichmann U, Reuter A, Vollmer S, Zhang F (2018b) Relationship between energy intensity and economic growth new evidence from a multi-country multi-sector data set (no. 8322)

Dong B, Zhang M, Mu H, Su X (2016) Study on decoupling analysis between energy consumption and economic growth in Liaoning Province. Energy Policy 97:414-420. https://doi.org/10.1016/j.enpol.2016.07.054 
Ethiopian Environmental Protection Agency (EEPA) (2004) The third national report on the implementation of the UNCCD/ NAP in Ethiopia

Evans P (1996) Using cross-country variances to evaluate growth theories. J Econ Dyn Control 20(6-7):1027-1049. https://doi. org/10.1016/0165-1889(95)00888-8

Ezcurra R (2007) Distribution dynamics of energy intensities: a cross-country analysis \$. Energy Policy 35:5254-5259. https:// doi.org/10.1016/j.enpol.2007.05.006

Farhani S, Ozturk I (2015) Causal relationship between $\mathrm{CO}_{2}$ emissions, real GDP, energy consumption, financial development, trade consumption, financial development, trade openness. Environ Sci Pollut Res. https://doi.org/10.1007/s1135 6-015-4767-1

Federal Democratic Republic of Ethiopia (FDRE) (2011) Ethiopia's climate-resilient green economy: green economy strategy. http://www.greengrowthknowledge.org/sites/default/files/downloads/policy-database/ETHIOPIA\%29Ethiopia\%27sCl imate-ResilientGreenEconomy-GreenEconomyStrategy.pdf. Accessed 2 Aug 2018

Filipovic S, Verbic M, Radovanovic M (2015) Determinants of energy intensity in the European Union: a panel data analysis. Energy 92:547-555. https://doi.org/10.1016/j.energy.2015.07.011

Galli R (1998) The relationship between energy intensity and income levels. Energy J 19(4):85-105

Gokmenoglu KK, Taspinar N (2018) Testing the agriculture-induced EKC hypothesis: the case of Pakistan. Environ Sci Pollut Res 5:89. https://doi.org/10.1007/s11356-018-2330-6

Hajko V (2014) The energy intensity convergence in the transport sector. Proc Econ Finance 12(March):199-205. https://doi. org/10.1016/S2212-5671(14)00336-0

Halicioglu F, Ketenci N (2016) The impact of international trade on environmental quality: the case of transition countries. Energy 109:1130-1138. https://doi.org/10.1016/j.energy.2016.05.013

Herrerias MJ (2012) World energy intensity convergence revisited: a weighted distribution dynamics approach \$. Energy Policy 49:383-399. https://doi.org/10.1016/j.enpol.2012.06.044

Hübler M, Keller A (2010) Energy savings via FDI? Empirical evidence from developing countries *. Environ Dev Econ 15(August):59-80

Hundie SK (2014) Savings, investment and economic growth in Ethiopia: evidence from ARDL approach to co-integration and TYDL Granger-causality tests. J Econ Int Finance 6(10):232-248. https://doi.org/10.5897/JEIF2014.0600

Hundie SK (2018) Modeling energy consumption, carbon dioxide emissions and economic growth nexus in Ethiopia: evidence from cointegration and causality analysis. Turk J Agric Food Sci Technol 6(6):699-709

Jakob M, Haller M, Marschinski R (2012) Will history repeat itself? Economic convergence and convergence in energy use patterns. Energy Econ 34(1):95-104. https://doi.org/10.1016/j.eneco.2011.07.008

Jiang L, Ji M (2016) China's energy intensity, determinants and spatial effects. Sustainability 8(544):1-15. https://doi. org/10.3390/su8060544

Jiang Z, Lin B (2012) China's energy demand and its characteristics in the industrialization and urbanization process. Energy Policy 49:608-615. https://doi.org/10.1016/j.enpol.2012.07.002

Jiang L, Folmer H, Ji M, Zhou P (2018) Revisiting cross-province energy intensity convergence in China: a spatial panel analysis. Energy Policy 121 (June):252-263. https://doi.org/10.1016/.enpol.2018.06.043

Jimenez R, Mercado J (2014) Energy intensity: a decomposition and counterfactual exercise for Latin American countries. Energy Econ 42:161-171. https://doi.org/10.1016/j.eneco.2013.12.015

Jones DW (1991) How urbanization affects energy-use in developing countries how urbanization affects energy-use in developing countries. Energy Policy 19:621-630. https://doi.org/10.1016/0301-4215(91)90094-5

Kander A, Warde P, Henriques ST, Nielsen H, Kulionis V, Hagen S (2017) International trade and energy intensity during European industrialization, 1870-1935. Ecol Econ 139:33-44. https://doi.org/10.1016/j.ecolecon.2017.03.042

Karimu A, Brannuld R, Lundgren T, Söderholm P (2017) Energy intensity and convergence in Swedish industry: a combined econometric and decomposition analysis. Energy Econ 62(February):347-356. https://doi.org/10.1016/j.eneco 2016.07.017

Katircioglu ST (2014) International tourism, energy consumption, and environmental pollution: the case of Turkey. Renew Sustain Energy Rev 36:180-187. https://doi.org/10.1016/.rser.2014.04.058

Kiran B (2013) Energy intensity convergence in OECD countries. Energy Explor Exploit 31(2):237-247

Lescaroux F (2011) Dynamics of final sectoral energy demand and aggregate energy intensity. Energy Policy 39(1):66-82. https://doi.org/10.1016/j.enpol.2010.09.010

Liddle B (2010) Revisiting world energy intensity convergence for regional differences. Appl Energy 87(10):3218-3225. https:// doi.org/10.1016/j.apenergy.2010.03.030

Liew VK (2014) Which lag length selection criteria should we employ? Economics Bulletin 3(33):1-9

Loayza N, Ranciere R (2005) Financial development, financial fragility, and growth (no. WP/05/170)

Lütkepohl H (2006) Structural vector autoregressive analysis for cointegrated variables. Mod Econom Anal Surv Recent Dev. https://doi.org/10.1007/3-540-32693-6_6

Luzzati TÃ, Orsini M (2009) Investigating the energy-environmental Kuznets curve. Energy 34:291-300. https://doi. org/10.1016/.energy.2008.07.006

Ma B, Yu Y (2017) Industrial structure, energy-saving regulations and energy intensity: evidence from Chinese cities. J Clean Prod 141(January):1539-1547. https://doi.org/10.1016/j.jclepro.2016.09.221

Mahmood T, Ahmad E (2018) The relationship of energy intensity with economic growth: evidence for European economies. Energy Strategy Rev. https://doi.org/10.1016/j.esr.2018.02.002

Medlock KB, Soligo R (2001) Economic development and end-use energy demand. Int Assoc Energy Econ 22(2):77-105

Metcalf G (2008) An empirical analysis of energy intensity and its determinants at the state level. Energy J 29(3):1-26

Mondal AH, Bryan E, Ringler C, Mekonnen D, Rosegrant M (2018) Ethiopian energy status and demand scenarios: prospects to improve energy efficiency and mitigate GHG emissions Ethiopian energy status and demand scenarios: prospects to improve energy efficiency and mitigate GHG emissions. Energy 149(February):161-172. https://doi.org/10.1016/j.energ y.2018.02.067

Moreau V, Vuille F (2018) Decoupling energy use and economic growth: counter evidence from structural effects and embodied energy in trade. Appl Energy 215(January):54-62. https://doi.org/10.1016/j.apenergy.2018.01.044 
Muhammad Q, Hye A, Leitao NC (2013) Economic growth, energy consumption, financial development, international trade and $\mathrm{CO}_{2}$ emissions in Indonesia. Renew Sustain Energy Rev. https://doi.org/10.1016/j.rser.2013.04.009

Mulder P, de Groot HLF (2012) Structural change and convergence of energy intensity across OECD countries, 1970-2005. Energy Econ 34(6):1910-1921

Narayan PK (2004) Reformulating critical values for the bounds F-statistics approach to cointegration: an application to the tourism demand model for (no. 02/04). Melbourne, Australia

Narayan PK (2005) The saving and investment nexus for China: evidence from cointegration tests. Appl Econ 37(17):19791990. https://doi.org/10.1080/00036840500278103

Narayan PK, Narayan S (2004) Savings behaviour in Fiji: an empirical assessment using the ARDL approach to cointegration. Department of Economics discussion papers no. 02/03, Monash University, Melbourne, Australia

Narayan PK, Smyth R (2005) What determines migration flows from low-income to high-income countries? An empirical investigation of Fiji-U.S. migration 1972-2001. Contemp Econ Policy 24(2):332-342. https://doi.org/10.1093/cep/byj019

O'Neill BC, Chen BS (2002) Determinants demographic use of household energy in the United States. Popul Dev Rev 28:53-88

Pen Y Le, Sévi B (2010) On the non-convergence of energy intensities: evidence from a pair-wise econometric approach ऊ. Ecol Econ 69(3):641-650. https://doi.org/10.1016/j.ecolecon.2009.10.001

Pesaran HH, Shin Y (1998) Generalized impulse response analysis in linear multivariate models. Econ Lett 58:17-29

Pesaran MH, Shin Y (1999) An autoregressive distributed lag modelling approach to cointegration analysis. In Econometrics and economic theory in the 20th century: The Ragnar Frisch centennial symposium. https://doi.org/10.1017/CCOL5 21633230

Phillips PC, Hansen BE (1990) Statistical inference in instrumental variables regression with I (1) processes. Rev Econ Stud 57(1):99-125. https://doi.org/10.2307/2297545

Quah D (1993) Galton's fallacy and tests of the convergence fallacy Galton's hypothesis. Scand J Econ 95(4):427-443

Rafiq S, Salim R, Nielsen I (2016) Urbanization, openness, emissions and energy intensity: a study of increasingly urbanized emerging economies. Energy Econ. https://doi.org/10.1016/j.eneco.2016.02.007

Ramakrishna G (2014) Energy consumption and economic growth: the Ethiopian experience. J Econ Financ Model 2(2):35-47

Rambaldi AN, Doran HE (1996) Testing for Granger non-causality in cointegrated systems made easy, 88

Richmond AK, Kaufmann RK (2006) Energy prices and turning points: the relationship between income and energy use/carbon emissions published by: International Association for Energy Economics Stable. http://www.jstor.org/stable/23297 037. REFERENCES Linked references are available. International Association for Energy Economics 27(4):157-180

Sadorsky P (2013) Do urbanization and industrialization affect energy intensity in developing countries? Energy Econ 37:52-59. https://doi.org/10.1016/.eneco.2013.01.009

Salim R, Yao Y, Chen G (2017) Does human capital matter for energy consumption in China? Energy Econ. https://doi. org/10.1016/..eneco.2017.05.016

Shahbaz M, Muhammad Q, Hye A, Kumar A, Carlos N (2013) Economic growth, energy consumption, financial development, international trade and $\mathrm{CO}_{2}$ emissions in Indonesia. Renew Sustain Energy Rev 25:109-121. https://doi.org/10.1016/j. rser.2013.04.009

Shahbaz M, Loganathan N, Sbia R, Afza T (2015) The effect of urbanization, affluence and trade openness on energy consumption: a time series analysis in Malaysia. Renew Sustain Energy Rev 47:683-693. https://doi.org/10.1016/j. rser.2015.03.044

Sineviciene L, Sotnyk I, Kubatko O (2017) Determinants of energy efficiency and energy consumption of Eastern Europe postcommunist economies. Energy Environ 28(8):870-884. https://doi.org/10.1177/0958305X17734386

Smil V (2003) Energy at the crossroads_ _ global perspectives and uncertainties. MIT Press, Cambridge. https://doi.org/10.1002/ joc.1346

Song F, Zheng X (2012) What drives the change in China's energy intensity: combining decomposition analysis and econometric analysis at the provincial level. Energy Policy 51:445-453. https://doi.org/10.1016/j.enpol.2012.08.044

Soni A, Mittal A, Kapshe M (2017) Energy Intensity analysis of Indian manufacturing industries. Resour EffTechnol 3(3):353357. https://doi.org/10.1016/j.reffit.2017.04.009

Toda HY, Yamamoto T (1995) Statistical inference in vector autoregressions with possibly integrated processes. Journal of Econometrics 66(1-2):225-250. https://doi.org/10.1016/0304-4076(94)01616-8

U.S. Energy Information and Administration (EIA) (2016) International energy outlook 2016: with projections to 2040. https:// www.eia.gov/outlooks/ieo/pdf/0484(2016).pdf

van Benthem AA (2015) Energy leapfrogging. J Assoc Environ Resour Econ. https://doi.org/10.1086/680317

van Benthem AA, Romani M (2009) Fuelling growth: what drives energy demand in developing countries? Energy J. https:// doi.org/10.5547/ISSN0195-6574-EJ-Vol30-No3-5

van Ruijven B, Urban F, Benders RMJ, Moll HC, van der Sluijs JP, de Vries B, van Vuuren DP (2008) Modeling energy and development: an evaluation of models and concepts. World Dev 36(12):2801-2821. https://doi.org/10.1016/j.world dev.2008.01.011

Yan H (2015) Provincial energy intensity in China: the role of urbanization. Energy Policy 86:635-650. https://doi.org/10.1016/j. enpol.2015.08.010

Zellner A (1962) An efficient method of estimating seemingly unrelated regressions and tests for aggregation bias. J Am Stat Assoc 57(298):348-368

Zhang D, Cao H, Wei Y (2016) Identifying the determinants of energy intensity in China: a Bayesian averaging approach. Appl Energy 168:672-682. https://doi.org/10.1016/j.apenergy.2016.01.134

Zivot E, Andrews DWK (1992) Further evidence on the great crash, the oil-price shock, and the unit-root hypothesis. Journal of Business andEconomic. Statistics. https://doi.org/10.1080/07350015.1992.10509904

\section{Publisher's Note}

Springer Nature remains neutral with regard to jurisdictional claims in published maps and institutional affiliations. 